\title{
Reinvestigating the phylogeny of Myriapoda with more extensive taxon sampling and novel genetic perspective
}

\author{
Jiajia Wang ${ }^{1}$, Yu Bai $^{1}$, Haifeng Zhao ${ }^{2}$, Ruinan $\mathrm{Mu}^{3}$, Yan Dong ${ }^{\text {Corresp. } 1}$ \\ ${ }^{1}$ College of Biology and Food Engineering, Chuzhou University, Chuzhou, Anhui, China \\ 2 Key Laboratory of Space Utilization, Technology and Engineering Center for Space Utilization, Chinese Academy of Sciences, Beijing, Beijing, China \\ 3 University of Chinese Academy of Sciences, Beijing, Beijing, China \\ Corresponding Author: Yan Dong \\ Email address: dongyan_bio@126.com
}

Background. There have been extensive debates on the interrelationships among the four major classes of Myriapoda-Chilopoda, Symphyla, Diplopoda, and Pauropoda. The core controversy is the position of Pauropoda; that is, whether it should be grouped with Symphyla or Diplopoda as a sister group. Two recent phylogenomic studies separately investigated transcriptomic data from 14 and 29 Myriapoda species covering all four groups along with outgroups, and proposed two different topologies of phylogenetic relationships. Methods. Building on these studies, we extended the taxon sampling by investigating 39 myriapods and integrating the previously available data with three new transcriptomic datasets generated in this study. Our analyses present the phylogenetic relationships among the four major classes of Myriapoda with a more abundant taxon sampling and provide a new perspective to investigate the above-mentioned question, where visual genes' identification were conducted. We compared the appearance pattern of genes, grouping them according to their classes and the visual pathways involved. Positive selection was detected for all identified visual genes between every pair of 39 myriapods, and 14 genes showed positive selection among 27 pairs. Results. From the results of phylogenomic analyses, we propose that Symphyla is a sister group of Pauropoda. This stance has also received strong support from tree inference and topology tests. 


\section{Reinvestigating the phylogeny of Myriapoda with more extensive taxon 2 sampling and novel genetic perspective}

3

4

Wang Jiajia ${ }^{1}$, Bai $\mathrm{Yu}^{1}$, Zhao Haifeng ${ }^{2}$, Mu Ruinan ${ }^{3}$, Dong Yan ${ }^{1 *}$

${ }^{1}$ College of Biology and Food Engineering, Chuzhou University, Chuzhou ,Anhui, China;

${ }^{2}$ Key Laboratory of Space Utilization, Technology and Engineering Center for Space Utilization, Chinese

Academy of Sciences, Beijing, China;

${ }^{3}$ University of Chinese Academy of Sciences, Beijing, China;

*Correspondence to: Dong Yan ${ }^{1}$, College of Biology and Food Engineering, Chuzhou University, Chuzhou 239000, China. Email: dongyan_bio@126.com.

\section{Abstract}

Background. There have been extensive debates on the interrelationships among the four major classes of Myriapoda - Chilopoda, Symphyla, Diplopoda, and Pauropoda. The core controversy is the position of Pauropoda; that is, whether it should be grouped with Symphyla or Diplopoda as a sister group. Two recent phylogenomic studies separately investigated transcriptomic data from 14 and 29 Myriapoda species covering all four groups along with outgroups, and proposed two different topologies of phylogenetic relationships.

Methods. Building on these studies, we extended the taxon sampling by investigating 39 myriapods and integrating the previously available data with three new transcriptomic datasets generated in this study. Our analyses present the phylogenetic relationships among the four major classes of Myriapoda with a more abundant taxon sampling and provide a new perspective to investigate the above-mentioned question, where visual genes' identification were conducted. We compared the appearance pattern of genes, grouping them according to their classes and the visual pathways involved. Positive selection was detected for all identified visual genes between every 
26 pair of 39 myriapods, and 14 genes showed positive selection among 27 pairs.

27 Results. From the results of phylogenomic analyses, we propose that Symphyla is a sister group 28 of Pauropoda. This stance has also received strong support from tree inference and topology tests. 29 Key words: Myriapoda, phylogenetic relationships, transcriptomic, positive selection, visual genes

\section{Introduction}

31 Myriapoda is a diverse group of terrestrial arthropods with more than 16,000 extant species(Moore, 2006) including millipedes and centipedes, which are familiar with our daily life. The presence of numerous legs (range from 6 to 750), which has given the myriapods their name, is obviously a symplesiomorphy(Marek \& Bond, 2006). Myriapoda are widely distributed on all continents except Antarctica, and their diversity is concentrated in tropical and temperate regions, where you can find evidence of their habitat in soil, tree barks and trunks, fields and pastures, deserts, caverns, and coastal areas(Santos-Silva et al., 2019). There is an extensive debate on the sister group to monophyletic Myriapoda. Pancrustacea and Chelicerata are the two candidates with most support(Giribet \& Edgecombe, 2019). There are four major classes of Myriapoda: Chilopoda (also known as centipedes, CHI), Diplopoda (also known as millipedes, DIP), Pauropoda (PAU), and Symphyla (SYM). Although the described extant species of all four classes are abundant, especially in CHI and DIP, the phylogenomic data are scarce(Szucsich et al., 2020). To date, only two phylogenomic studies have collected genome-wide or transcriptome-wide sequencing data covering all four classes for phylogeny investigation. Results from both studies supported monophyletic Myriapoda and the monophyly of each major class (DIP, CHI, PAU, and SYM)(Fernández, Edgecombe \& Giribet, 2018; Szucsich et al., 2020)'(Bäcker, Fanenbruck \& Wägele, 2008). However, the interrelationships among the four classes are still controversial.

48 Previous molecular analyses proposed the PAU+SYM grouping (named Edafopoda), which 49 strongly contradicted the sister-group relationship DIP+PAU (named Dignatha). And the 50 hypothesis Edafopoda was supported by morphology and development(Regier et al., 2010; Regier 
52

53

54

55

56

57

58

59

60

61

62

63

64

65

66

67

68

69

70

71

72

73

74

et al., 2020).

3 With the emergence of Next-Generation Sequencing (NGS) technology, some clarity has been gained in recent years. Fernández et al. sequenced 12 myriapods, which greatly enriched the available data for phylogenomic analyses(Fernández, Edgecombe \& Giribet, 2018). Their results strongly support Dignatha topology with grouping PAU+DIP. A strong dependence on the choice of outgroups was emphasised in their study. In 2020, Szucsich et al. generated 22 Myriapod RNASequencing data by analysing 59 species(Szucsich et al., 2020). In addition to tree inference and outgroup selection impact testing, they conducted two topology tests: approximate unbiased (AU) tests and four-cluster likelihood-mapping (FcLM). Their results were consistent with Edafopoda topology, thereby grouping PAU+SYM(Szucsich et al., 2020). It is worth noting that both studies, although suggesting diverging topologies of the interrelationships among Myriapoda, placed Myriapoda as a sister group to Pancrustacea.

4 These two seminal works on the interrelationships of Myriapoda have laid a good foundation in phylogenomic data for further study. In our study, 60 species were investigated, including 39 Myriapoda members and 21 outgroups. We integrated data from the two aforementioned studies with three newly sequenced transcriptome data (one chilopod: Scolopendra sp.; and two diplopods: Epanerchodus sp., Skleroprotopus sp.). We compiled two concatenated supermatrices covering all four major classes of Myriapoda and three clades of outgroups, one including 20 gene partitions and the other, 369. We performed phylogenetic tree inference using Maximum-Likelihood method. The resulting trees had the same topology as Edafopoda (PAU+SYM) and a sister group of DIP $+\mathrm{CHI}$, which was consistent with previous research results proposed by Szucsich et al(Szucsich et al., 2020). As shown in the previous study proposed by Szucsich et al, Pancrustacea is the closest relative to Myriapoda. Furthermore, topology tests including an AU test, weighted Kishino-Hasegawa $(\mathrm{KH})$ test, and weighted Shimodaira-Hasegawa $(\mathrm{SH})$ test were conducted on six topology hypotheses derived from the two most controversial phylogenetic relationships (Edafopoda and Dignatha). The results showed that almost all hypotheses derived from Dignatha 
were rejected with high probability. The topologies of PAU+SYM and DIP+CHI, which were determined from our best Maximum-Likelihood (ML) tree, survived all the tests. We attempted to find additional evidence to support PAU+SYM, and found that almost all species of PAU and SYM were small-sized, blind and soil-dwelling, which may have a significant impact on visual capabilities. For the evolution of vision-related genes, we performed Light Interaction Toolkit (LIT) gene identification on each of the 39 Myriapoda species and conducted positive selection analyses on the identified LIT genes. The distribution of LIT gene identification shared a very similar pattern among the four major classes, however, positive selection evidence was narrowed in CHI\&DIP, CHI\&PAU, CHI\&SYM, DIP\&PAU, and DIP\&SYM.

\section{Material and methods}

\section{Taxon sampling}

Building upon previous works by Fernández et al. and Szucsich et al.(Fernández, Edgecombe \& Giribet, 2018; Szucsich et al., 2020), where more than 36 species representing the four major groups of myriapods were included in taxon sampling, we sequenced three additional species (one chilopod: Scolopendra sp.; and two diplopods: Epanerchodus sp., Skleroprotopus sp.) in this study. Our sampling was designed to maximise the representation of myriapod groups. Information on sampling localities and accession numbers in the Sequence Read Archive (SRA) database for each transcriptome is shown in Table 1, including four genomes from http://metazoa.ensembl.org. Twenty-one outgroups were also included: eight chelicerates (Liphistius malayanus, Centruroides vittatus, Damon diadema, Archegozetes longisetosus, Araneus diadematus, Egaenus convexus, Euscorpius sicanus, and Nymphon gracile), two onychophorans (Peripatopsis capensis and Peripatoides novaezealandiae), and 11 pancrustaceans (Daphnia pulex, Folsomia candida, Drosophila melanogaster, Eubranchipus grubii, Triops cancriformis, Nebalia bipes, Anaspides tasmaniae, Hemidiaptomus amblyodon, Tisbe furcata, Vargula hilgendorfii, and Xibalbanus tulumensis). 


\section{RNA extraction and sequencing}

106 Following the manufacturer's instructions, total RNA was extracted using a commercial RNA

107 extraction kit (TAKARA). Samples were treated with Ambion turbo DNA-free DNase to remove

108 residual genomic and rRNA contaminants during mRNA purification. The quantity and quality

109 (purity and integrity) of mRNA were assessed using a NanoDrop ND-2000 UV spectrophotometer

110 (Thermo Fisher Scientific).

111 For mRNA sequencing library preparation, mRNA was first enriched and purified with oligo (dT)-

112 rich magnetic beads and then broken into short fragments, followed by paired-end sequencing on

113 an Illumina Hiseq 4000 platform.

\section{Data processing and de novo assembly}

116 Sequencing adaptors and low-quality sequences were trimmed using Trimmomatic v 0.36

117 (Bolger, Lohse \& Usadel, 2014) with default parameters. The clean data were assembled with

118 Trinity (release 2.11.0) with 100 GB memory and a path reinforcement distance of 50 (Grabherr

119 et al., 2011). The redundancy of all assembled transcripts was removed using CD-HIT v. 4.8.1

120 (under the cd-hit-est mode, with default parameters(Li \& Godzik, 2006)). TransDecoder v5.5.0

121 (https:/github.com/TransDecoder/TransDecoder) was then utilised for nucleotide sequence

122 translation and longest ORF selection.

123

\section{Orthology assignment and phylogenetic matrix construction}

125 Both classical pipeline (OrthoFinder) and single-copy gene selection method (Benchmarking

126 Universal Single-Copy Orthologs; BUSCO) were used in orthology assignment among the 60

127 selected taxa. Orthogroups were first identified using OrthoFinder v 2.2.7(Emms \& Kelly, 2015)

128 with default settings (BLASTP E value $\leq 1 \mathrm{e}-5$ and MCL inflation parameter of 1.5). Single-copy

129 genes in arthropods were identified in our datasets with BUSCO v4.1.4 with default settings (E

130 value $\leq 1 \mathrm{e}-6$ ) based on hidden Markov model profiles, where BUSCO dataset arthropoda_odb10 
131 (https://busco-data.ezlab.org/v4/data/lineages) was used as reference(Seppey, Manni \& Zdobnov,

132 2019). For each BUSCO and each taxon, the longest hit of duplicated BUSCO homologous genes

133 was retained for further analysis.

134 Putative orthogroup filtering was based on the gene occupancy threshold, which means that

135 an orthogroup (or BUSCO) was selected if it could be found in more than or equal to the threshold

136 number of taxa. For example, a 50\% gene occupancy threshold would select orthogroups that were

137 present in $\geq 50 \%$ of the included taxa. We selected two thresholds of $100 \%$ and $90 \%$ gene

138 occupancy to obtain information on most species and to minimise the computational burden.

139 Protein sequences of each orthogroup were aligned with MAFFT v 7.305b (maxiterate was set to

1401000 in globalpair mode) prior to concatenation(Katoh \& Standley, 2013). Then, Aliscore v2.0

141 was used to perform each orthogroup's multiple sequence alignment (MSA) for ambiguous or

142 randomly aligned sections' identification, followed by Alicut v2.2 for error section's

143 trimming(Kück, 2009). After filtering with 100\% and 90\% gene occupancy thresholds, two raw

144 matrices were constructed using custom Python scripts. Finally, the matrices were trimmed using

145 MARE (v 0.1.2) to select optimised data subsets from the supermatrices for phylogenetic

146 inference(Meyer, Meusemann \& Misof, 2011).

147

\section{Best partition schemes finding}

149 The best-fit partitioning schemes and models of evolution for phylogenetic analyses were

150 searched and estimated with PartitionFinderV2.0.0(Lanfear et al., 2017), where amino acid

151 substitution models were restricted to LG, WAG, JTT, and BLOSUM62. The corrected Akaike

152 Information Criterion (AICc) model was selected and was set under greedy search.

153

\section{Phylogenetic tree inference}

\section{Maximum-Likelihood tree}

156 Tree searches were performed for the two supermatrices with a ML approach, using IQ-TREE

157 (v1.6.12) with the above best partitioning schemes. Statistical support was derived from 100 non- 
158 parametric slow bootstrap replicates. Replicates to perform SH-like approximate likelihood ratio

159 test were set to 1000 and unsuccessful iterations to stop were set to 300 . The initial tree searches

160 were set from a completely random tree(Nguyen et al., 2015). The full command was: 'iqtree -s

161 MSAmatrix.phy -alrt 1000 -b 100 -t RANDOM -spp partition_file. nex-nstop 300.'

162

163 Bootstrap support inference

164 Bootstrapping analyses were applied with RAxML-NG v1.0.0(Kozlov et al., 2019), and the

165 autoMRE bootstrap convergence test was set for a sufficient number of replicates. The bootstrap

166 support was then mapped onto the phylogenetic trees using RAxML v8.2.11(Stamatakis, 2014).

167

168

Topology testing

To evaluate support for the different hypotheses concerning the relationship proposed by previous studies among the four major classes within Myriapoda, topology tests were run for each dataset using the corresponding best partition scheme with IQ-TREE (v1.6.12), where the AU-test, weighted KH-test, and weighted SH-test were included, and all tests performed 100,000 resamplings using the resampling of estimated log-likelihoods (RELL) method(Nguyen et al.,

174 2015). Six proposed hypotheses representing the two most controversial phylogenetic

175 relationships (Edafopoda and Dignatha) of four major classes in Myripoda were compared in our

176 topology tests; detailed information is shown in Figure 1.

177 Hypothesis Eda.1(topology: ((CHI,DIP), (SYM, PAU)); ).

178 Hypothesis Eda.2(topology: (CHI, (DIP, (SYM, PAU))); ).

179 Hypothesis Eda.3(topology: (DIP, (CHI, (SYM, PAU))); ).

180 Hypothesis Dig.1(topology: ((CHI, SYM), (DIP, PAU)); ).

181 Hypothesis Dig.2(topology: (CHI, (SYM, (DIP, PAU))); ).

182 Hypothesis Dig.3(topology: (SYM, (CHI, (DIP, PAU))); ).

183

Identification of LIT genes 
185 A modified version of the phylogenetically informed annotation tool pipeline named PIA2

186 (https://github.com/xibalbanus/PIA2) was applied for the identification of visual opsins in this

187 study, and the parameters were set default(Pérez-Moreno et al., 2018). In this pipeline, 111 genes

188 from the LIT, a collection of genes that underlie the function or development of light-interacting

189 structures in metazoans, representing 13 different parts in visual pathways (photoreceptor

190 specification, retinal determination network, phototransduction, rhabdomeric, phototransduction,

191 ciliary, retinoid pathway, vertebrate, retinoid pathway, invertebrate, melanin synthesis, pterin

192 synthesis, ommochrome synthesis, heme synthesis, crystallins, diurnal clock, and opsin), was

193 taken as reference (Speiser et al., 2014). We applied the pipeline to protein sequences of each

194 species.

195

196 Identification of positively selected genes

197 Evidence of positive selection was indicated by estimating the ratios of nonsynonymous

198 substitutions ( $\mathrm{Ka}$ or $\mathrm{dN}$ ) and synonymous substitutions (Ks or dS), also called substitution rates

199 (Ka/Ks or $\mathrm{dN} / \mathrm{dS}$ value). The coding sequence of each identified LIT genes was aligned between

200 a pair of taxa separately with MAFFT v 7.305b with default settings. And then the substitution rate

201 was calculated using the KaKs_calculator with the following settings, method of calculation:

202 GMYN, genetic code table: The Echinoderm and Flatworm Mitochondrial Code(Wang et al., 203 2010).

\section{Results}

206 Transcriptome assembly and phylogenomic dataset construction

207 NGS technologies have empowered phylogenomic analyses in the last few decades. It has

208 dramatically increased the size of datasets applied to phylogenetic questions. Within the

209 framework of combining NGS technologies and phylogenomic techniques, we decided to re-

210 investigate Myriapoda phylogeny with three newly sequenced species. Combined with published

211 data from two outstanding studies on Myriapoda phylogeny, the data from a total of 60 species (39 
212 from Myriapoda, 8 Chelicerata, 11 Crustacea, and 2 Onychophora) were used in this study (Table

213 1)(Fernández, Edgecombe \& Giribet, 2018; Szucsich et al., 2020). Except for the four species with

214 published genome data, raw reads of the remaining 56 species were trimmed and assembled de

215 novo. Orthology assignments of the 60 species were mainly based on BUSCO results, and more

216 than $70 \%$ of the ortholog gene set (BUSCO dataset: arthropoda_odb10, comprising 1013 single-

217 copy protein-coding genes or ortholog group, OG) were identified in 56 species (details in

218 Supplementary Table 1). Additionally, 786 of the BUSCO orthology assignments were confirmed

219 using OrthoFinder (details in Supplementary Table 1).

220 Concatenated supermatrices were compiled using a threshold of percentage gene occupancy of

$221 \quad 100 \%$ and 90\% (Figure 2)(González et al., 2015). We found that 32 OGs were represented in all

22260 species (100\% gene occupancy), of which 20 were confirmed by OrthoFinder. There were 505

223 OGs represented in more than 54 species (90\% gene occupancy), and 369 OG assignments were

224 confirmed by OrthoFinder. Thus, two datasets comprising 20 and 369 OGs were obtained (

225 Supplementary Table 1). After MSA, identification, and removal of ambiguously aligned sections

226 in each dataset, two phylogenomic supermatrices on the amino acid levels were constructed, which

227 are hereafter referred to as OCC100 and OCC90. Matrix OCC100 included 20 gene partitions and

228 spanned 8,401 aligned sites with 0.395 overall information content. Matrix OCC90 included 369

229 gene partitions and spanned 129,085 aligned sites with 0.318 overall information content.

230

231 Phylogenetic tree inference and topology analysis

232 We constructed Maximum-Likelihood (ML) trees based on the best partition schemes and

233 best-fitting substitution models schemes with matrices OCC100 and OCC90. Three main results

234 were found from the inferred trees. All the analyses recovered Myriapoda as the monophyletic

235 sister group of Pancrustacea with high support (Figure 3). As for the relationships among the four

236 myriapod classes: Symphyla (SYM), Chilopoda (CHI), Diplopoda (DIP), and Pauropoda (PAU),

237 we found a sister group relationship of CHI+DIP, and another sister group relationship of

238 PAU+SYM (Figure 3). Both were highly supported by the bootstrap result (PAU+SYM: 100\%, 
239 DIP+CHI: 100\%). The three newly sequenced species (Scolopendra sp., Epanerchodus sp., and

240 Skleroprotopus sp.) were positioned in the expected clades.

241 A variety of groupings of the Myriapoda classes have been proposed, where two hypotheses,

242 Edafopoda and Dignatha, received the most attention (Figure 1). Edafopoda is a grouping of

243 PAU+SYM which has been supported by shared genetic sequences (Figure 1). However, in

244 Dignatha, the PAUs were positioned with the DIPs. In this study, all trees inferred were congruent

245 with the unrooted quartet topology with CHI+DIP and PAU+SYM (Hypothesis Eda.1, Figure 1).

246 We conducted three types of topology tests-AU test, $\mathrm{KH}$ test, and weighted $\mathrm{SH}$ test - on the

247 quartet topology of Edafopoda and Dignatha, where four different phylogenomic datasets were

248 applied. The results consistently supported the topology Hypothesis Eda.1, which is the only

249 topology to not be rejected in any test (Table 2). Almost all hypotheses derived from Dignatha

250 were rejected with high significance, especially in the phylogenomic matrix OCC90 (Table 2).

251 When comparing the results from the two phylogenomic matrices, we found that all testing results

252 of matrix OCC100 were consistent with and covered by that of matrix OCC90. Under matrix

253 OCC90, the datasets that were different in outgroup selection (PAN or CHE) exclusively showed

254 divergence when rejecting Hypothesis Eda.2, where all three topology tests on the datasets with

255 CHE were not rejected, which was completely opposite to the results of datasets with PAN (Table

256 2). In other words, we found that the sister group of Edafopoda (PAU+SYM) received less support

257 from $\mathrm{CHI}$ than the clade of $\mathrm{DIP}+\mathrm{CHI}$, but it cannot be completely denied.

258

259 Outgroup dependence of myriapod phylogeny inference

260 Despite the quartet topology of CHI+DIP and PAU+SYM being recovered in our analyses,

261 the relationships among the four major classes in Myriapoda varied across phylogenomic datasets,

262 with dependence on outgroup selection proposed in previous studies(Fernández, Edgecombe \&

263 Giribet, 2018; Szucsich et al., 2020). Given that the phylogeny inference was sensitive to outgroup

264 choice, we conducted topology tests on datasets with different clades of outgroups: one with only

265 CHE as outgroup, and the other with only PAN (Supplementary Figure 2-5). ML tree inference of

Peer] reviewing PDF | (2021:08:64880:1:1:NEW 20 Nov 2021) 
266 the former resulted in a sister group relationship of CHI+DIP and another sister group relationship

267 of PAU+SYM, which was congruent with the results inferred from the datasets with the full taxon

268 sampling (Figure 3). However, we found that the ML tree inferred from the latter datasets resulted

269 in a sister group relationship of CHI and DIP, with SYM as a sister to this clade, followed by PAU.

270 Although these quartet topology results were also obtained in previous studies, negligible support

271 could be obtained from bootstrapping analyses(Szucsich et al., 2020).

272

273

LIT genes' identification in Myriapoda

274 Using the PIA2 pipeline, we identified 2,001 transcripts in 39 Myriapoda species as putative components involved in the development of light-interacting structures, including 96 LIT genes, which are important components of 11 visual pathways (Figure 4). A total of 13 visual pathways were compiled in the pipeline, and two were absent in this study (Table 3, retinal determination network and opsin synthesis) which involved 10 LIT genes. In addition, the other five absent LIT genes were $G q \_$gamma, RBP3, Dat, TYR, and reflectin_la. We investigated the completeness of the amino acid level of each ortholog by calculating the ratio of the length of the identified peptide to the target reference peptide, as depicted in Figure 4; the lighter the cell-filling colour, the more incomplete the transcript. As shown in Figure 4, the distribution patterns of the identified LIT genes among the four classes are very similar; LIT genes from prc (photoreceptor specification), reti (retinoid pathway, invertebrate), heme (heme synthesis), and crys (crystallins) were rarely identified in Myriapoda (shown as a large blank area in Figure 4). We also found that LIT genes from reti (retinoid pathway, invertebrate, 0 ), ommo (ommochrome synthesis, 2), and clock (diurnal classes, we found that 62 LIT genes could be identified in at least one of the four classes (Figure 5c), and three $(G C, T H, K F)$ could be identified in all 39 myriapods investigated. The following ciliary, mel: melanin synthesis, and ommo: ommochrome synthesis. We compared the LIT genes 
293 the genes participated (Figure 5b and Figure 5a). We found that clock (diurnal clock), crys

294 (crystallins), ommo (ommochrome synthesis), and reti (retinoid pathway, invertebrate) were more

295 abundant in the sister group of DIP and CHI.

296

297 Selection tests on LIT genes

298 To test whether genes associated with the evolution of light interactions in Myriapoda have

299 undergone potentially adaptive changes, $\mathrm{Ka} / \mathrm{Ks}$ calculations were conducted. A total of 23,832

300 aligned LIT gene pairs were calculated, including 8,717 pairs from CHI\&DIP, 2,048 from

301 CHI\&SYM, 1,220 from CHI\&PAU, 1,158 from DIP\&PAU, 1,981 from DIP\&SYM, 278 from

302 PAU\&SYM, 4,241 from CHI\&CHI, 3,981 from DIP\&DIP, 47 from PAU\&PAU, and 161 from

303 SYM\&SYM. Positive selection was detected in 27 pairs, indicated by $\mathrm{Ka} / \mathrm{Ks} \geq 1$, five pairs from

304 CHI\&DIP, one from CHI\&PAU, three from CHI\&SYM, two from DIP\&PAU, two from

305 DIP\&SYM, seven from CHI\&CHI, and seven from DIP\&DIP. As depicted in Figure 5, no

306 evidence of positive selection for LIT genes was found in PAU\&PAU, SYM\&SYM, PAU\&SYM.

307 Values of $\mathrm{Ka} / \mathrm{Ks}$ in the range of 0.5 to 1.0 , which indicates relaxed selection, were observed in 395

308 pairs, covering all classes combinations (details in Supplementary Table 2). The remaining 23,435

309 pairs had $\mathrm{Ka} / \mathrm{Ks}$ values ranging from 0.0002 to 0.5 , representing $98 \%$ of the pairs we calculated,

310 which means that most of the genes in the four major classes were under purifying selection.

311 Positive selection was detected in the following 14 LIT genes: clot, Cngal, CSAD, DAGK, DDC,

312 Galpha_it, GC, Gprkl, Gq_alpha, Pde6abc, PKC, PLC, RBPI, RDH8, timeless, and trp, which

313 cover the clock, ctrans, mel, pter, retv, and rtrans visual pathways (Figure 6). In addition, the

314 transient receptor potential protein trp, which encodes a component of the rhabdomeric

315 phototransduction pathway, was identified and positively selected in PAU\&CHI, SYM\&CHI, and

316 SYM\&DIP.

317

318

319 Tables and Figures

Peer) reviewing PDF | (2021:08:64880:1:1:NEW 20 Nov 2021) 
320

321

322

323

324

325

326

327

328

329

330

331

332

333

334

335

336

337

338

339

340

341

342

343

344

345

346

347

348

349

350

351

352

353

354

\section{Table 1. Taxon sampling}

Species included in this study SRA accession numbers(Brewer \& Bond, 2013; Fernández et al., 2014; Sharma et al., 2014; Fernández, Edgecombe \& Giribet, 2016, 2018; Szucsich et al., 2020), information collection, and data sources are indicated.

\section{Table 2. Results of topology tests}

Results of approximately unbiased (AU), weighted Kishino-Hasegawa (KH), and weighted Shimodaira-Hasegawa (SH) tests comparing historically proposed hypotheses of the inner relationships of Myriapoda. A total of 100,000 RELL replicates were performed for each test, plus signs (+) denote the $95 \%$ confidence sets (not rejected), minus signs (-) denote significant exclusion (rejected).

\section{Table 3. Distribution of LIT genes' identification}

Statistical results of LIT gene identification. Sum: the sum of transcripts from a specific class that was identified as LIT genes involved in a specific visual pathway. Max: the maximum quantity of transcripts from a species among a specific class that was identified as the LIT genes involved in a specific visual pathway. Mean: ratio of the sum and species quantity of a specific class.

Figure 1. Hypotheses on relationships of the major myriapod lineages Chilopoda, Diplopoda, Symphyla and Pauropoda

Hypothesis Eda.1, Hypothesis Eda.2 and Hypothesis Eda.3 are three quartet topologies derived from Edafopoda, which grouping the PAU and SYM as a sister clade; Hypothesis Dig.1, Hypothesis Dig.2 and Hypothesis Dig.3 are three quartet topologies derived from Dignatha, which grouping the PAU and DIP as a sister clade.

\section{Figure 2. Schematic of the two supermatrices used in this study.}

Matrix OCC100 was based on the blue section (100\% gene occupancy) where 32 BUSCOs were included, and matrix OCC90 was based on the purple and blue section ( $>90 \%$ gene occupancy) where 505 BUSCO were included.

\section{Figure 3. Best ML tree on matrix OCC90}

Best Maximum-Likelihood tree inferred with IQ-TREE derived from matrix OCC90 (60 taxa, alignment length: 129,085 amino acid positions, 369 gene partitions), and rooted with Onychophora, where all the topology were consistent with the best ML tree inferred from matrix OCC100. Statistical support was derived from 1,000 non-parametric bootstrap replicates, trees were converged after 700 replicates.

\section{Figure 4. LIT genes identified in four major subgroups of Myriapoda}

Tree structure on the left of the figure was the best ML tree in this study. The colorful cells represent the completeness on aminoacid level of each ortholog by calculating the ratio of the length of the identified peptide and the target reference one provided in the PIA2. The lighter of the cell filling color, the more incomplete the transcript. Abbreviations of the visual pathways are following,

Peer] reviewing PDF | (2021:08:64880:1:1:NEW 20 Nov 2021) 
355

356

357

358

359

360

361

362

363

364

365

366

367

368

369

370

371

372

373

374

\section{Discussion}

376

377

378

379

380

381

382

383

PRC: Photoreceptor Specification, RTRANS: Phototransduction, Rhabdomeric, CTRANS: Phototransduction, Ciliary, RETV: Retinoid Pathway, Vertebrate, RETI: Retinoid Pathway, Invertebrate, MEL: Melanin Synthesis, PTER: Pterin Synthesis, OMMO: Ommochrome Synthesis, HEME: Heme Synthesis, CRYS: Crystallins, CLOCK: Diurnal Clock.

\section{Figure 5. Comparison of the LIT genes in four main subgroups of Myriapoda}

Co-identified LIT genes grouping by visual pathways between PAU and SYM (a), DIP and CHI (b). Number of distinct LIT genes identified among each monophyletic subgroup of Myriapoda.

\section{Figure 6. Positive selection support for LIT genes by $\mathrm{Ka} / \mathrm{Ks}$ calculation}

Subgroup distribution of the positively selected genes, the bigger the bubbles, the more pairs found under positive selection, and the smallest bubbles mean the support was one.

Supplementary Table 1. Ortholog group assignment

Supplementary Table $2 . \mathrm{Ka} / \mathrm{Ks}$ results of LIT genes

Supplementary Figure 1. ML tree on matrix OCC100

Supplementary Figure 2. ML tree on matrix OCC90 without outgroups from Pancrustacea

Supplementary Figure 3. ML tree on matrix OCC100 without outgroups from Pancrustacea

Supplementary Figure 4. ML tree on matrix OCC90 without outgroups from Chelicerata

Supplementary Figure 5. ML tree on matrix OCC100 without outgroups from Chelicerata

In this study, we first performed phylogenomic analyses on Myriapoda with three newly sequenced members by integrating phylogenetic tree inference and topology testing. Our results showed that $\mathrm{CHI}+\mathrm{DIP}$ and PAU+SYM were the best quartet topologies for interrelationships among the four major classes. This is consistent with the recent study by Szucsich et al., but in conflict with the earlier results published by Fernández et al. and with morphological evidence(Fernández, Edgecombe \& Giribet, 2018; Szucsich et al., 2020). We provided an innovative point in taxon sampling, which was the addition of three newly sequenced Myriapoda species with high-quality sequencing, two of which were members of DIP and one of CHI. It is 
384 particularly worth mentioning that the taxon sampling of the PAU class in this study was

385 represented by two species (Pauropus huxleyi and Acopauropus ornatus), instead of just one 386 specie in previous studies which may increase the risk of mispositioning PAU in quartet topology.

387 Previous studies have shown that, in molecular studies, the more extensive a taxon sample 388 collection, the more convincing the phylogeny results(Fernández, Edgecombe \& Giribet, 2018; 389 Szucsich et al., 2020).

390 There seems to be no end to the debate about the interrelationships among the four main 391 Myriapoda classes, though phylogenomic analyses do provide robust evidence for phylogeny, 392 where novel research points were being summoned. We then turned our study's focus on the 393 common environmental and ecological habits and conditions of most species of PAU and SYM.

394 The pauropods (PAU) inhabit a variety of soil types, but sometimes found in plant litter and 395 decaying logs, and they cannot burrow themselves, which makes them be confined to crevices and 396 tunnels already present(Adis et al., 2002). Besides, they are small-sized with little mobility, which 397 can be the reason for that they rarely appear outside the Amazonian sampling sites(Battirola et al., 398 2018; Hilgert et al., 2019; Santos-Silva et al., 2019). Though symphylans (SYM) most often are 399 true soil-dwellers, they can live in many different habitats: in leaf litter, in the upper humus layer, 400 and in pure soil, both in upper layers and in the mineral subsoil(Adis et al., 2002). In summary, 401 most species of PAU and SYM are small-sized, soil-dwelling and blind, while most of CHI and 402 DIP are eyed. It cannot be denied that these characters are shared with some orders of DIP and 403 CHI. The order Geophilomorpha (comprise over 1,254 species) and the family Cryptopidae (order 404 Scolopendromorpha, comprise over 184 species) of the class CHI (comprise over 4,142 species) 405 are both live underground and blind(Adis et al., 2002; Borja \& Rincón, 2017), which accounts for 406 a third of the CHI. In class DIP, order Polydesmida, order Platydesmida, order Glomeridesmida 407 separately comprise over 3,500, 50 and 30 species, which accounts for almost a half of the DIP 408 (comprise over 7,753 species) (Adis et al., 2002; Borja \& Rincón, 2017). However, almost all 409 species of PAU (comprise over 835 species) and SYM (comprise over 197 species) were blind and 
410 soil-dwelling(Adis et al., 2002; Borja \& Rincón, 2017). It could be due to biases in species

411 richness, but we insisted that visual capability was a good innovation point, and made a preliminary

412 exploration. With the help of analytical pipeline developed for whole-genome wide identification

413 of visual genes(Speiser et al., 2014; Pérez-Moreno et al., 2018), we identified visual genes for each

414 of the 39 Myriapoda species separately, and compared the distribution of positively selected genes

415 among the four major classes. As our results showed, positive selection was detected between

416 species from CHI and DIP, CHI and PAU, CHI and SYM, DIP and PAU, DIP and SYM, but none

417 was found between PAU and SYM. Both, the LIT gene identification and the positive selection,

418 indicated that the components of the rhabdomeric phototransduction pathway, which are employed

419 by the photoreceptors found in the eyes of many invertebrates, received the most attention (Figure

4205 and Figure 6). The majority of the components of the rhabdomeric phototransduction pathway

421 are responsible for conferring light sensitivity to photoreceptors from the retinas of

422 cephalopods(Mitchell \& Mayeenuddin, 1998; Kishigami et al., 2001; Murakami \& Kouyama, 423 2008), including Gq protein, r-opsins, and transient receptor potential protein. The positive 424 selection pressure on trp in PAU\&CHI, SYM\&CHI, and SYM\&DIP could reflect adaptive 425 changes in the machinery during the rhabdomeric phototransduction pathway. In this respect, the 426 positive selection signatures on the components of the rhabdomeric phototransduction pathway in 427 Myriapoda could be regarded and further analysed from a broader perspective. Besides, blind 428 species account for more than a third in both CHI and DIP, thus LIT genes' patterns between eyed 429 CHI and blind CHI, eyed DIP and blind DIP, warrants further study.

430 Although phylogenomic data covering 39 myriapods have been published, the acquisition of 431 more sufficient data is still expected, especially transcriptomic data from species in PAU and 432 SYM. To address the interrelationships of the four major classes of Myriapoda, we consolidated 433 most of the available data for Myriapoda phylogeny analyses, and conducted a series of 434 phylogenomic analyses, which provided strong evidence for the PAU+SYM topology of 435 Edafopoda. To find other evidence for Edafopoda, we identified visual genes that detected positive 
436 selection pressure among the four major classes of Myriapoda. In short, our analyses offered more

437 information to further promote the study of interspecific evolutionary relationships among

438 Myriapoda.

439

440 Conclusion

441 For the highly disputed interrelationships of Myriapoda, our best phylogenetic tree involved

44239 species favored the hypothesis Edafopoda, which was supported by a series of topology tests

443 we conducted and consistent with plenty of previous studies. The commonness of living habits

444 was investigated among the four major classes, and we made a preliminary exploration by LIT

445 analyses. Though weak evidence was found to support the monophyly of PAU and SYM, we think

446 it is a good research point, which needs further study.

\section{Acknowledgments}

448 This work was supported by the Natural Science Foundation of the Higher Education Institutions

449 of Anhui Province (KJ2018ZD041) and the Key Program in the Youth Elite Support Plan in 450 Universities of Anhui Province (gxyqZD2020045).

\section{Authors' contributions}

452 DY conceived and designed the experiments. DY and WJJ contributed to paper writing. ZHF and

453 MUN conducted the experiment. WJJ and BY contributed to the data analysis.

\section{Disclosure statement}

455 No potential conflict of interest was reported by the author(s).

456 Availability of data and materials 
457 The data are presented in the manuscript and the supporting materials. The raw reads data are 458 submitted to the Short Read Archive (SRA) and BioProject accession number 459 PRJNA758760(https://www.ncbi.nlm.nih.gov/bioproject/PRJNA758760).

460

\section{References}

462 Adis J, Foddai D, Golovatch SI, Hoffman RL, Minelli A, de Morais JW, Pereira LA, Scheller U, 463 Schileyko AA, Würmli M. 2002. Myriapoda at "Reserva Ducke", central Amazonia/Brazil. 464 Amazoniana 17:15-25.

465 Bäcker H, Fanenbruck M, Wägele JW. 2008. A forgotten homology supporting the monophyly 466 of Tracheata: The subcoxa of insects and myriapods re-visited. Zoologischer Anzeiger 467 247:185-207. DOI: 10.1016/j.jcz.2007.11.002.

468 Battirola LD, Golovatch SI, Pinheiro TG, Batistella DA, Rosado-Neto GH, Chagas A, Brescovit 469 AD, Marques MI. 2018. Myriapod (Arthropoda, Myriapoda) diversity and distribution in a 470 floodplain forest of the Brazilian Pantanal. Studies on Neotropical Fauna and Environment 53:62-74. DOI: 10.1080/01650521.2017.1397978.

Bolger AM, Lohse M, Usadel B. 2014. Trimmomatic: A flexible trimmer for Illumina sequence data. Bioinformatics 30:2114-2120. DOI: 10.1093/bioinformatics/btu170.

Borja R, Rincón B. 2017. Reference Module in Life Sciences.

475 Brewer MS, Bond JE. 2013. Ordinal-level phylogenomics of the arthropod class Diplopoda 476 (millipedes) based on an analysis of 221 nuclear protein-coding loci generated using next477 generation sequence analyses. PLOS ONE 8. DOI: 10.1371/journal.pone.0079935.

478 Dong Y, Sun H, Guo H, Pan D, Qian C, Hao S, Zhou K. 2012. The complete mitochondrial 479 genome of Pauropus longiramus (Myriapoda: Pauropoda): Implications on early 480 diversification of the myriapods revealed from comparative analysis. Gene 505:57-65. DOI: 481 10.1016/j.gene.2012.05.049. 
482 Emms DM, Kelly S. 2015. OrthoFinder: solving fundamental biases in whole genome 483 comparisons dramatically improves orthogroup inference accuracy. Genome Biology 484 16:157. DOI: 10.1186/s13059-015-0721-2.

485 Fernández R, Edgecombe GD, Giribet G. 2016. Exploring Phylogenetic Relationships within 486 Myriapoda and the Effects of Matrix Composition and Occupancy on Phylogenomic 487 Reconstruction. Systematic Biology 65:871-889. DOI: 10.1093/sysbio/syw041.

488 Fernández R, Edgecombe GD, Giribet G. 2018. Phylogenomics illuminates the backbone of the 489 Myriapoda Tree of Life and reconciles morphological and molecular phylogenies. Scientific 490 Reports 8:83. DOI: 10.1038/s41598-017-18562-w.

491 Fernández R, Laumer CE, Vahtera V, Libro S, Kaluziak S, Sharma PP, Pérez-Porro AR, 492 Edgecombe GD, Giribet G. 2014. Evaluating topological conflict in centipede phylogeny 493 using transcriptomic data sets. Molecular Biology and Evolution 31:1500-1513. DOI: $494 \quad 10.1093 / \mathrm{molbev} / \mathrm{msu} 108$.

495 Giribet G, Edgecombe GD. 2019. The Phylogeny and Evolutionary History of Arthropods. 496 Current Biology 29:R592-R602. DOI: 10.1016/j.cub.2019.04.057.

497 González VL, Andrade SCS, Bieler R, Collins TM, Dunn CW, Mikkelsen PM, Taylor JD, 498 Giribet G. 2015. A phylogenetic backbone for Bivalvia: An RNA-seq approach.

499 Proceedings of the Royal Society B: Biological Sciences 282:20142332. DOI:

$500 \quad 10.1098 / \mathrm{rspb} .2014 .2332$.

501 Grabherr MG, Haas BJ, Yassour M, Levin JZ, Thompson DA, Amit I, Adiconis X, Fan L, 502 Raychowdhury R, Zeng Q, Chen Z, Mauceli E, Hacohen N, Gnirke A, Rhind N, Di Palma 503 F, Birren BW, Nusbaum C, Lindblad-Toh K, Friedman N, Regev A. 2011. Full-length 504 transcriptome assembly from RNA-Seq data without a reference genome. Nature 505 Biotechnology 29:644-652. DOI: 10.1038/nbt.1883.

506 Hilgert M, Akkari N, Rahmadi C, Wesener T. 2019. The Myriapoda of Halimun-Salak National 507 Park (Java, Indonesia): Overview and faunal composition. Biodiversity Data Journal 7. 
DOI: 10.3897/BDJ.7.e32218.

509 Katoh K, Standley DM. 2013. MAFFT multiple sequence alignment software version 7:

510 Improvements in performance and usability. Molecular Biology and Evolution 30:772-780.

$511 \quad$ DOI: $10.1093 / \mathrm{molbev} / \mathrm{mst} 010$.

512 Kishigami A, Ogasawara T, Watanabe Y, Hirata M, Maeda T, Hayashi F, Tsukahara Y. 2001.

513 Inositol-1,4,5-trisphosphate-binding proteins controlling the phototransduction cascade of

514 invertebrate visual cells. Journal of Experimental Biology 204:487-493. DOI:

$515 \quad 10.1242 /$ jeb.204.3.487.

516 Kozlov AM, Darriba D, Flouri T, Morel B, Stamatakis A. 2019. RAxML-NG: A fast, scalable

517 and user-friendly tool for maximum likelihood phylogenetic inference. Bioinformatics

518 35:4453-4455. DOI: 10.1093/bioinformatics/btz305.

519 Kück P. 2009. ALICUT: a Perlscript which cuts ALISCORE identified RSS. Department of

520 Bioinformatics, Zoologisches Forschungsmuseum A. Koenig (ZFMK), Bonn, Germany,

521 version 2.

522 Lanfear R, Frandsen PB, Wright AM, Senfeld T, Calcott B. 2017. Partitionfinder 2: New

523 methods for selecting partitioned models of evolution for molecular and morphological

524 phylogenetic analyses. Molecular Biology and Evolution 34:772-773. DOI:

$525 \quad 10.1093 / \mathrm{molbev} / \mathrm{msw} 260$.

526 Li W, Godzik A. 2006. Cd-hit: A fast program for clustering and comparing large sets of protein

527 or nucleotide sequences. Bioinformatics 22:1658-1659. DOI:

$528 \quad$ 10.1093/bioinformatics/btl158.

529 Marek PE, Bond JE. 2006. Rediscovery of the world's leggiest animal. Nature 441:707. DOI:

$530 \quad 10.1038 / 441707 a$.

531 Meyer B, Meusemann K, Misof B. 2011. MARE: MAtrix REduction-a tool to select optimized 532 data subsets from supermatrices for phylogenetic inference. Bonn (Germany): Zentrum fuur 533 molekulare Biodiversit\{ä\}tsforschung (zmb) am ZFMK. 
534 Mitchell J, Mayeenuddin LH. 1998. Purification, G protein activation, and partial amino acid 535 sequence of a novel phospholipase C from squid photoreceptors. Biochemistry 37:90645369072 . DOI: $10.1021 /$ bi972768a.

537 Miyazawa H, Ueda C, Yahata K, Su ZH. 2014. Molecular phylogeny of Myriapoda provides 538 insights into evolutionary patterns of the mode in post-embryonic development. Scientific 539 Reports 4. DOI: 10.1038/srep04127.

540 Moore J. 2006. An Introduction to the Invertebrates: Chelicerata and Myriapoda. 10.1017/CB:181-191.

Murakami M, Kouyama T. 2008. Crystal structure of squid rhodopsin. Nature 453:363-367.

543 DOI: $10.1038 /$ nature 06925.

544 Nguyen LT, Schmidt HA, Von Haeseler A, Minh BQ. 2015. IQ-TREE: A fast and effective 545 stochastic algorithm for estimating maximum-likelihood phylogenies. Molecular Biology 546 and Evolution 32:268-274. DOI: 10.1093/molbev/msu300.

547 Pérez-Moreno JL, DeLeo DM, Palero F, Bracken-Grissom HD. 2018. Phylogenetic annotation 548 and genomic architecture of opsin genes in Crustacea. Hydrobiologia 825:159-175. DOI: 10.1007/s10750-018-3678-9.

Regier JC, Shultz JW, Zwick A, Hussey A, Ball B, Wetzer R, Martin JW, Cunningham CW. 2010. Arthropod relationships revealed by phylogenomic analysis of nuclear protein-coding sequences. Nature 463:1079-1083. DOI: 10.1038/nature08742.

Regier JC, Zwick A. 2011. Sources of signal in 62 protein-coding nuclear genes for higher-level phylogenetics of arthropods. PLOS ONE 6. DOI: 10.1371/journal.pone.0023408.

Santos-Silva L, Golovatch SI, Pinheiro TG, Chagas-Jr A, Marques MI, Battirola LD. 2019.

556 Myriapods (Arthropoda, myriapoda) in the Pantanal of Poconé, Mato Grosso, Brazil. Biota 557 Neotropica 19. DOI: 10.1590/1676-0611-bn-2018-0631.

558 Seppey M, Manni M, Zdobnov EM. 2019. BUSCO: Assessing genome assembly and annotation 559 completeness. Methods in Molecular Biology 1962:227-245. DOI: 10.1007/978-1-4939- 
9173-0_14.

561 Sharma PP, Kaluziak ST, Pérez-Porro AR, González VL, Hormiga G, Wheeler WC, Giribet G.

562 2014. Phylogenomic interrogation of arachnida reveals systemic conflicts in phylogenetic

563 signal. Molecular Biology and Evolution 31:2963-2984. DOI: 10.1093/molbev/msu235.

564 Speiser DI, Pankey MS, Zaharoff AK, Battelle BA, Bracken-Grissom HD, Breinholt JW, Bybee

565 SM, Cronin TW, Garm A, Lindgren AR, Patel NH, Porter ML, Protas ME, Rivera AS, Serb

566 JM, Zigler KS, Crandall KA, Oakley TH. 2014. Using phylogenetically-informed

567

568

569

570

571

572

573

574

575

576 annotation (PIA) to search for light-interacting genes in transcriptomes from non-model organisms. BMC Bioinformatics 15:350. DOI: 10.1186/s12859-014-0350-x.

Stamatakis A. 2014. RAxML version 8: A tool for phylogenetic analysis and post-analysis of arge phylogenies. Bioinformatics 30:1312-1313. DOI: 10.1093/bioinformatics/btu033.

Szucsich NU, Bartel D, Blanke A, Böhm A, Donath A, Fukui M, Grove S, Liu S, Macek O, Machida R, Misof B, Nakagaki Y, Podsiadlowski L, Sekiya K, Tomizuka S, Von Reumont BM, Waterhouse RM, Walzl M, Meng G, Zhou X, Pass G, Meusemann K. 2020. Four myriapod relatives - but who are sisters? No end to debates on relationships among the four major myriapod subgroups. BMC Evolutionary Biology 20. DOI: 10.1186/s12862-020-

577

578

579

580

581

582 583 01699-0.

Wang D, Zhang Y, Zhang Z, Zhu J, Yu J. 2010. KaKs_Calculator 2.0: A Toolkit Incorporating Gamma-Series Methods and Sliding Window Strategies. Genomics, Proteomics and Bioinformatics 8:77-80. DOI: 10.1016/S1672-0229(10)60008-3.

Zwick A, Regier JC, Zwickl DJ. 2012. Resolving Discrepancy between Nucleotides and Amino Acids in Deep-Level Arthropod Phylogenomics: Differentiating Serine Codons in 21Amino-Acid Models. PLoS ONE 7:e47450. DOI: 10.1371/journal.pone.0047450. 


\section{Figure 1}

Hypotheses_on_relationships_of_the_major_myriapod_lineages_Chilopoda,_Diplopoda,_S ymphyla_and_Pauropoda

Hypothesis Eda.1, Hypothesis Eda.2 and Hypothesis Eda.3 are three quartet topologies derived from Edafopoda, which grouping the PAU and SYM as a sister clade; Hypothesis Dig.1, Hypothesis Dig.2 and Hypothesis Dig.3 are three quartet topologies derived from Dignatha, which grouping the PAU and DIP as a sister clade. 

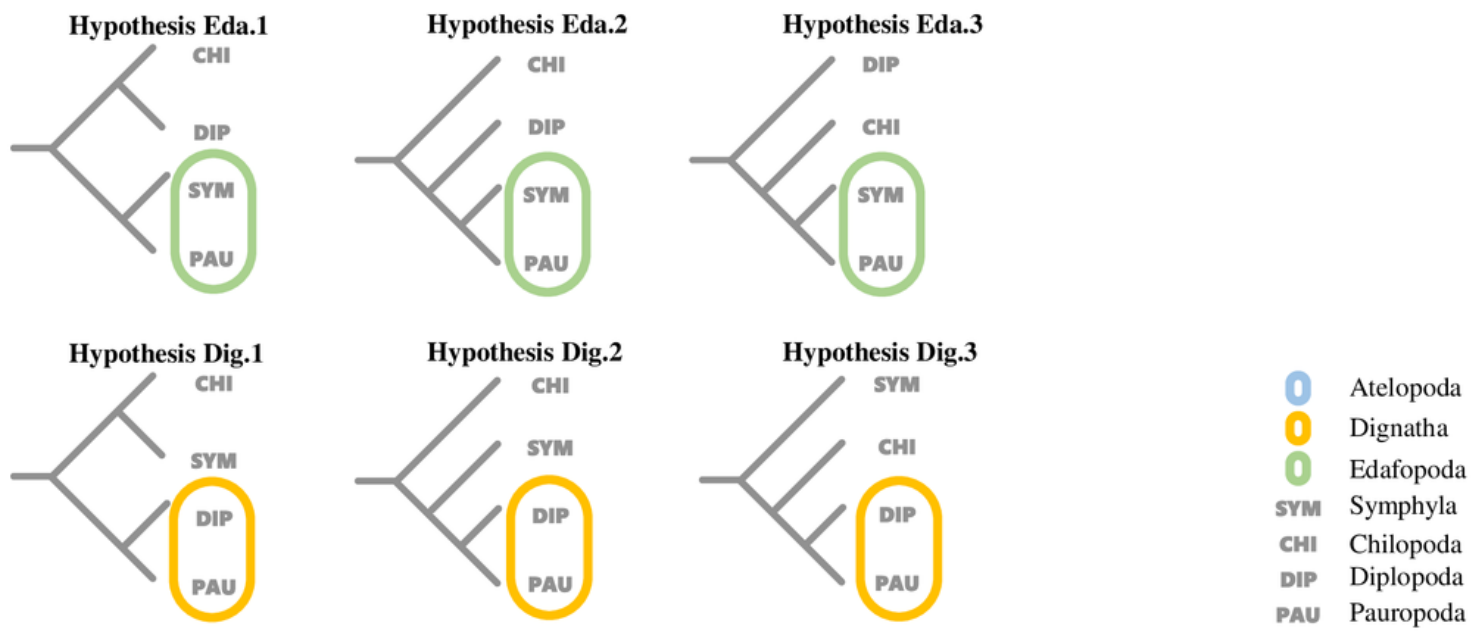


\section{Figure 2}

Schematic_of_the_two_supermatrices_used_in_this_study

Matrix OCC100 was based on the blue section (100\% gene occupancy) where 32 BUSCOs were included, and matrix OCC90 was based on the purple and blue section ( $>90 \%$ gene occupancy) where 505 BUSCO were included.

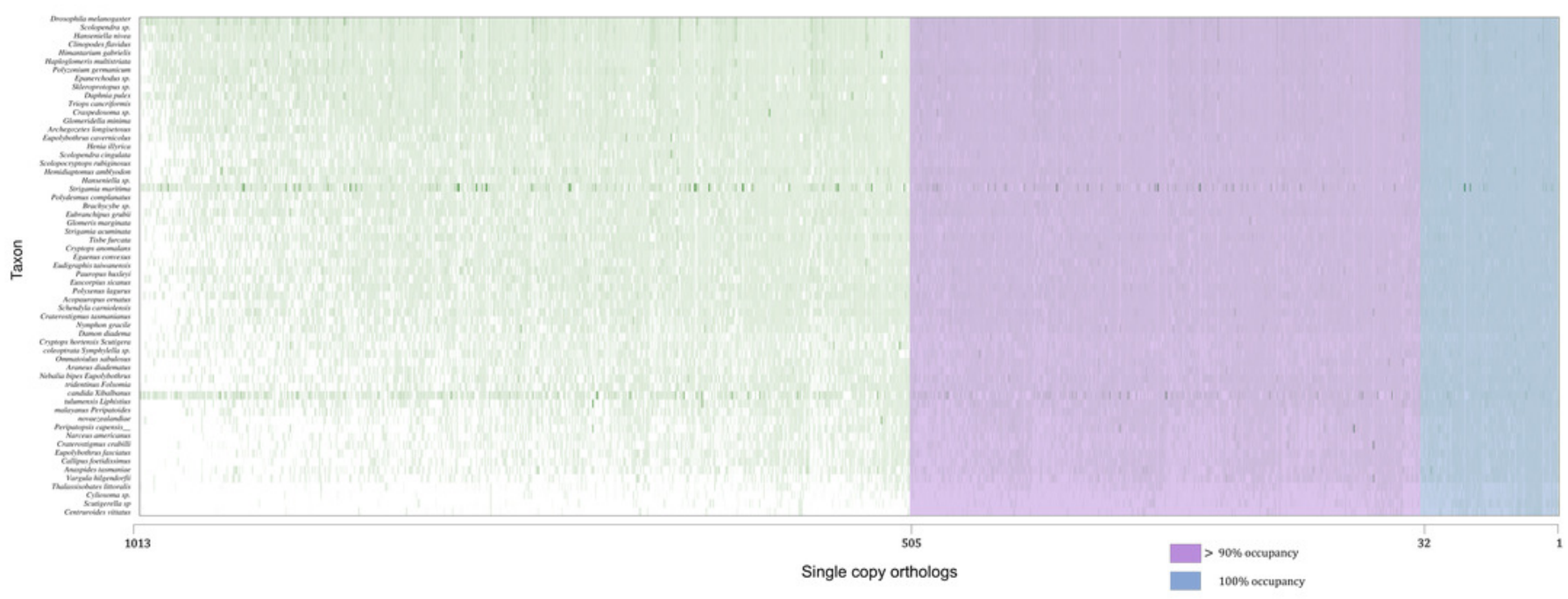


Figure 3

Best_ML_tree_on_matrix_ocC90

Best Maximum-Likelihood tree inferred with IQ-TREE derived from matrix OCC90 (60 taxa, alignment length: 129,085 amino acid positions, 369 gene partitions), and rooted with Onychophora, where all the topology were consistent with the best ML tree inferred from matrix OCC100. Statistical support was derived from 1,000 non-parametric bootstrap replicates, trees were converged after 700 replicates. 

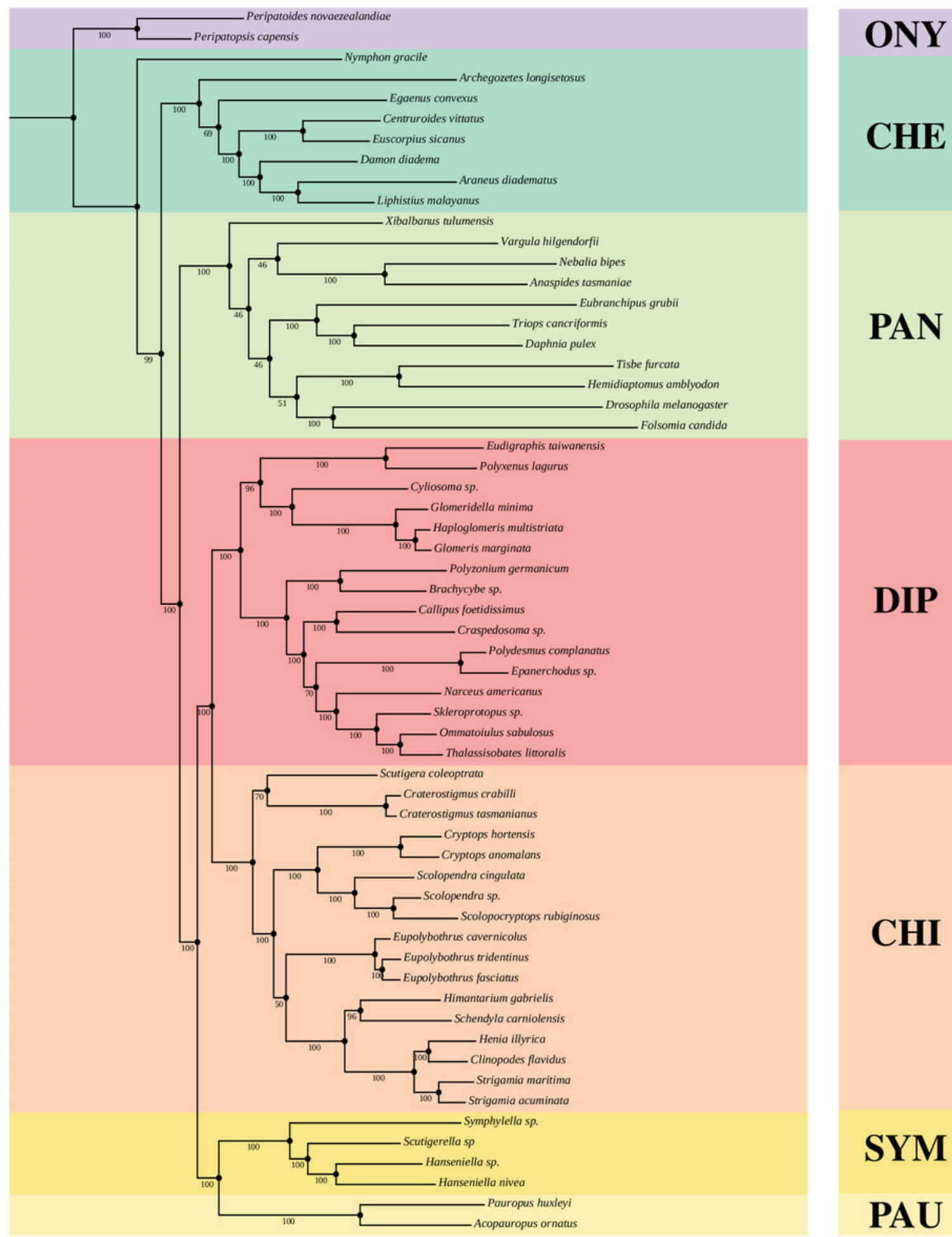

PAN

DIP

CHI

SYM

PAU

Tree scale: $0.1 \longmapsto$ 


\section{Figure 4}

LIT_genes_identified_in_four_major_subgroups_of_Myriapoda

Tree structure on the left of the figure was the best ML tree in this study. The colorful cells represent the completeness on amino-acid level of each ortholog by calculating the ratio of the length of the identified peptide and the target reference one provided in the PIA2. The lighter of the cell filling color, the more incomplete the transcript. Abbreviations of the visual pathways are following, PRC: Photoreceptor Specification, RTRANS: Phototransduction, Rhabdomeric, CTRANS: Phototransduction, Ciliary, RETV: Retinoid Pathway, Vertebrate, RETI: Retinoid Pathway, Invertebrate, MEL: Melanin Synthesis, PTER: Pterin Synthesis, OMMO: Ommochrome Synthesis, HEME: Heme Synthesis, CRYS: Crystallins, CLOCK: Diurnal Clock.

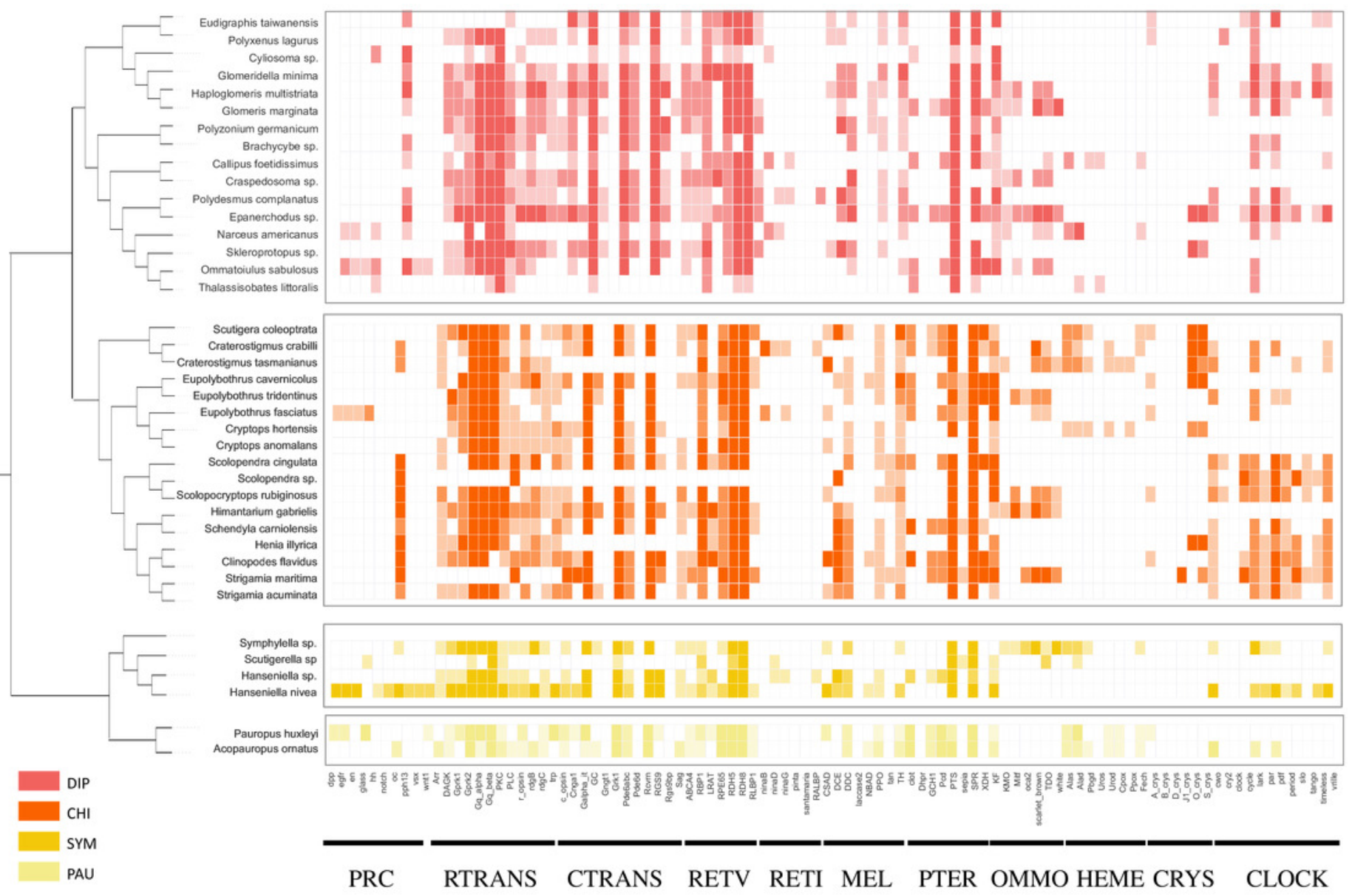


Figure 5

Comparison_of_the_LIT_genes_in_four_main_subgroups_of_Myriapoda

Co-identified LIT genes grouping by visual pathways between PAU and SYM (a), DIP and CHI (b). Number of distinct LIT genes identified among each monophyletic subgroup of Myriapoda. 
a

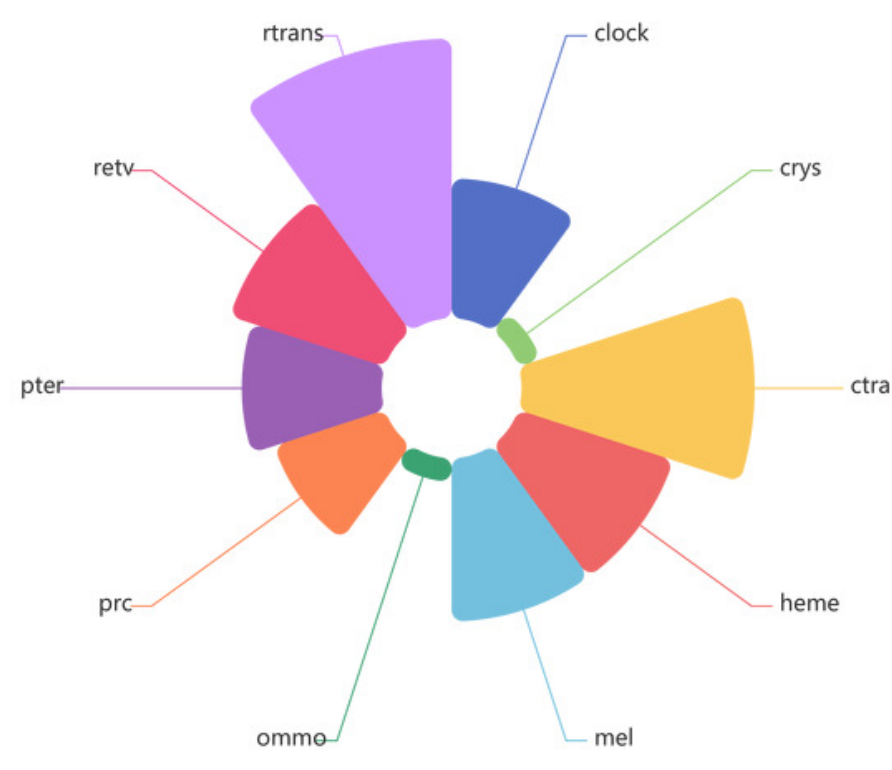

C
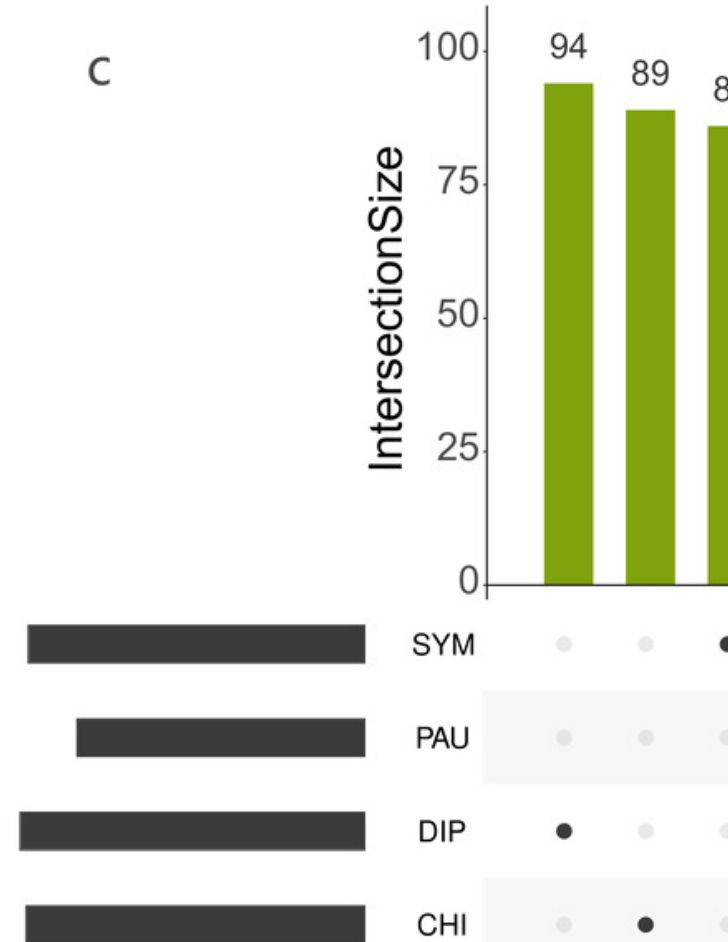

600 b

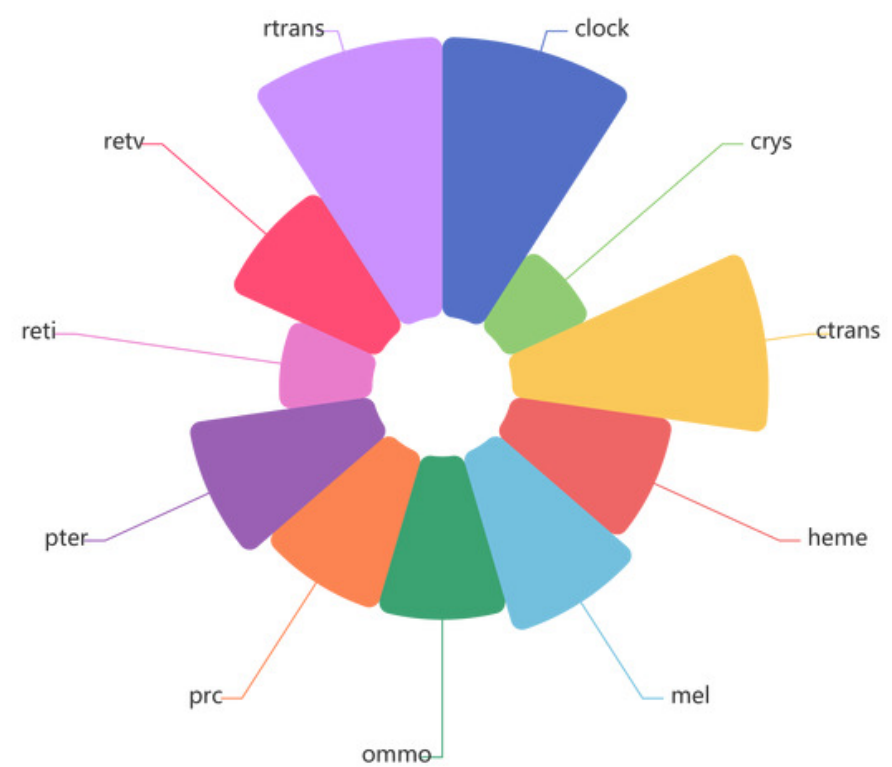

ommo

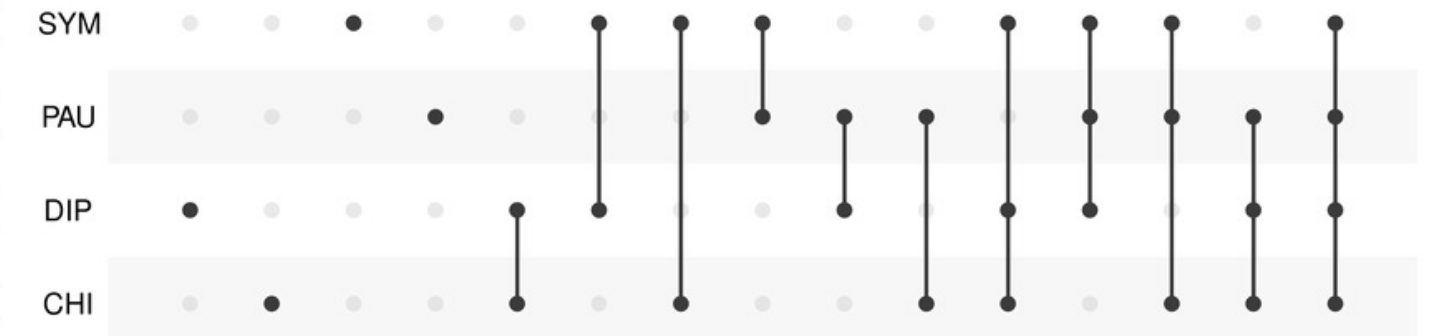


Figure 6

Positive_selection_support_for_LIT_genes_by_KaKs_calculation

Subgroup distribution of the positively selected genes, the bigger the bubbles, the more pairs found under positive selection, and the smallest bubbles mean the support was one.
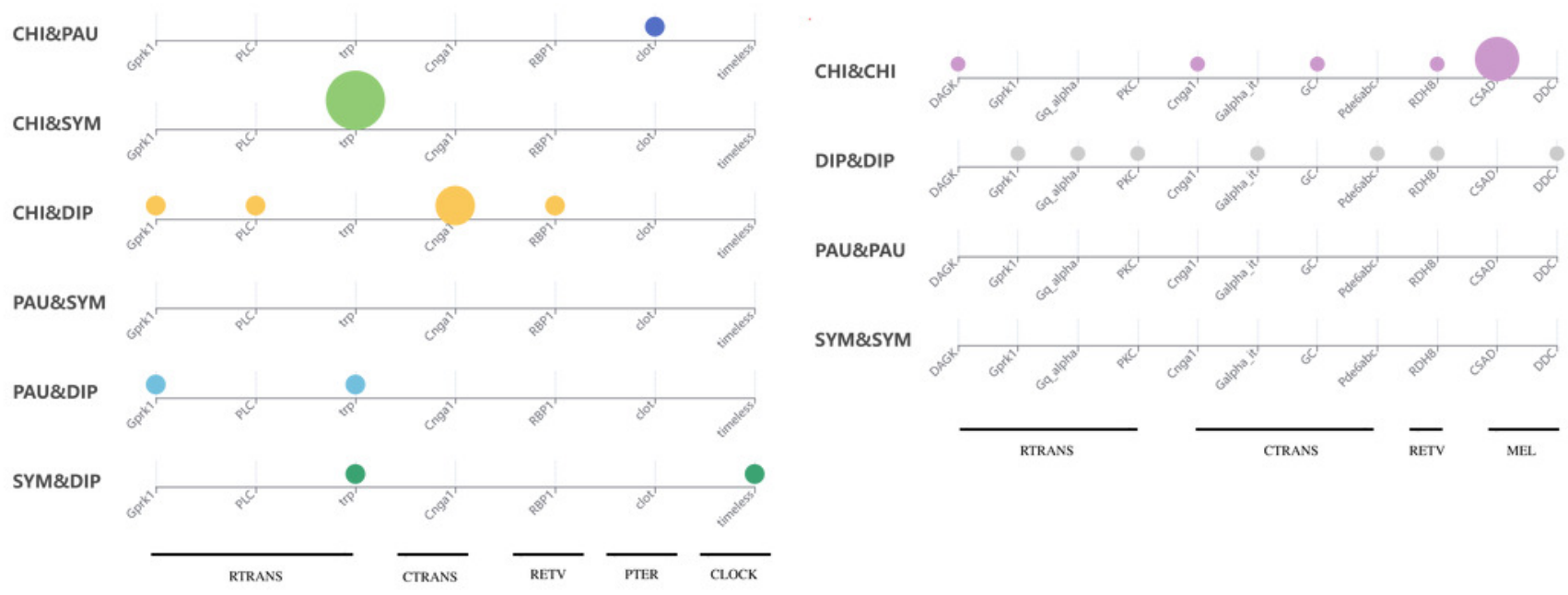


\section{Table $\mathbf{1}$ (on next page)}

Taxon_sampling

Species included in this study SRA accession numbers, information collection, and data sources are indicated. 


\begin{tabular}{|c|c|c|c|c|c|c|c|}
\hline Taxonomy & Clade Alias & Species & DataType & Source & SRA \# & Species Alias & \\
\hline $\begin{array}{l}\text { Myriapoda, } \\
\text { Chilopoda }\end{array}$ & $\mathrm{CHI}$ & $\begin{array}{c}\text { Eupolybothrus } \\
\text { cavernicolus }\end{array}$ & Transcriptome & $\begin{array}{c}\text { Fernández et al. } \\
2014\end{array}$ & ERR338470 & Spe01 & $\begin{array}{c}\text { Eupolybothrus } \\
\text { cavernicolus }\end{array}$ \\
\hline $\begin{array}{l}\text { Myriapoda, } \\
\text { Chilopoda }\end{array}$ & $\mathrm{CHI}$ & Cryptops hortensis & Transcriptome & $\begin{array}{c}\text { Fernández et al. } \\
2016\end{array}$ & SRR1153457 & Spe02 & Cryptops hortensis \\
\hline $\begin{array}{l}\text { Myriapoda, } \\
\text { Chilopoda }\end{array}$ & $\mathrm{CHI}$ & Scutigera coleoptrata & Transcriptome & $\begin{array}{c}\text { Fernández et al. } \\
2014\end{array}$ & SRR1158078 & Spe03 & Scutigera coleoptrata \\
\hline $\begin{array}{l}\text { Myriapoda, } \\
\text { Chilopoda }\end{array}$ & $\mathrm{CHI}$ & $\begin{array}{c}\text { Craterostigmus } \\
\text { crabilli }\end{array}$ & Transcriptome & $\begin{array}{c}\text { Fernández et al. } \\
2014\end{array}$ & SRR3232915 & Spe04 & $\begin{array}{c}\text { Craterostigmus } \\
\text { crabilli }\end{array}$ \\
\hline $\begin{array}{l}\text { Myriapoda, } \\
\text { Chilopoda }\end{array}$ & $\mathrm{CHI}$ & Strigamia maritima & Genome & Chipman et al. 2014 & -- & Spe05 & Strigamia maritima \\
\hline $\begin{array}{l}\text { Myriapoda, } \\
\text { Chilopoda }\end{array}$ & $\mathrm{CHI}$ & Scolopendra sp. & Transcriptome & This study & & Spe06 & Scoropendra sp. \\
\hline $\begin{array}{l}\text { Myriapoda, } \\
\text { Chilopoda }\end{array}$ & $\mathrm{CHI}$ & $\begin{array}{c}\text { Craterostigmus } \\
\text { tasmanianus }\end{array}$ & Transcriptome & Szucsich et al., 2020 & SRR2774008 & Spe31 & $\begin{array}{c}\text { Craterostigmus } \\
\text { tasmanianus }\end{array}$ \\
\hline $\begin{array}{l}\text { Myriapoda, } \\
\text { Chilopoda }\end{array}$ & $\mathrm{CHI}$ & Henia illyrica & Transcriptome & Szucsich et al., 2020 & SRR3485986 & Spe32 & Henia illyrica \\
\hline $\begin{array}{l}\text { Myriapoda, } \\
\text { Chilopoda }\end{array}$ & $\mathrm{CHI}$ & Clinopodes flavidus & Transcriptome & Szucsich et al., 2020 & SRR1653181 & Spe33 & Clinopodes flavidus \\
\hline $\begin{array}{l}\text { Myriapoda, } \\
\text { Chilopoda }\end{array}$ & $\mathrm{CHI}$ & $\begin{array}{c}\text { Himantarium } \\
\text { gabrielis }\end{array}$ & Transcriptome & Szucsich et al., 2020 & SRR1653198 & Spe34 & $\begin{array}{c}\text { Himantarium } \\
\text { gabrielis }\end{array}$ \\
\hline $\begin{array}{l}\text { Myriapoda, } \\
\text { Chilopoda }\end{array}$ & $\mathrm{CHI}$ & Strigamia acuminata & Transcriptome & Szucsich et al., 2020 & SRR3485997 & Spe35 & Strigamia acuminata \\
\hline $\begin{array}{l}\text { Myriapoda, } \\
\text { Chilopoda }\end{array}$ & $\mathrm{CHI}$ & $\begin{array}{c}\text { Schendyla } \\
\text { carniolensis }\end{array}$ & Transcriptome & Szucsich et al., 2020 & SRR3485996 & Spe36 & $\begin{array}{c}\text { Schendyla } \\
\text { carniolensis }\end{array}$ \\
\hline $\begin{array}{l}\text { Myriapoda, } \\
\text { Chilopoda }\end{array}$ & $\mathrm{CHI}$ & $\begin{array}{c}\text { Eupolybothrus } \\
\text { fasciatus }\end{array}$ & Transcriptome & Szucsich et al., 2020 & SRR3485981 & Spe37 & $\begin{array}{c}\text { Eupolybothrus } \\
\text { fasciatus }\end{array}$ \\
\hline Myriapoda, & $\mathrm{CHI}$ & Eupolybothrus & Transcriptome & Szucsich et al., 2020 & SRR3485982 & Spe38 & Eupolybothrus \\
\hline
\end{tabular}




\begin{tabular}{|c|c|c|c|c|c|c|c|}
\hline Chilopoda & & tridentinus & & & & & tridentinus \\
\hline $\begin{array}{l}\text { Myriapoda, } \\
\text { Chilopoda }\end{array}$ & $\mathrm{CHI}$ & Cryptops anomalans & Transcriptome & Szucsich et al., 2020 & SRR3485978 & Spe39 & Cryptops anomalans \\
\hline $\begin{array}{l}\text { Myriapoda, } \\
\text { Chilopoda }\end{array}$ & $\mathrm{CHI}$ & $\begin{array}{c}\text { Scolopendra } \\
\text { cingulata }\end{array}$ & Transcriptome & Szucsich et al., 2020 & SRR1653235 & Spe40 & $\begin{array}{c}\text { Scolopendra } \\
\text { cingulata }\end{array}$ \\
\hline $\begin{array}{l}\text { Myriapoda, } \\
\text { Chilopoda }\end{array}$ & $\mathrm{CHI}$ & $\begin{array}{c}\text { Scolopocryptops } \\
\text { rubiginosus }\end{array}$ & Transcriptome & Szucsich et al., 2020 & SRR1653236 & Spe41 & $\begin{array}{c}\text { Scolopocryptops } \\
\text { rubiginosus }\end{array}$ \\
\hline $\begin{array}{c}\text { Myriapoda, } \\
\text { Diplopoda }\end{array}$ & DIP & Glomeris marginata & Transcriptome & $\begin{array}{c}\text { Fernández et al. } \\
2016 \\
\end{array}$ & SRR3233211 & Spe11 & Glomeris marginata \\
\hline $\begin{array}{l}\text { Myriapoda, } \\
\text { Diplopoda }\end{array}$ & DIP & Narceus americanus & Transcriptome & $\begin{array}{c}\text { Fernández et al. } \\
2016\end{array}$ & SRR3233222 & Spe12 & Narceus americanus \\
\hline $\begin{array}{l}\text { Myriapoda, } \\
\text { Diplopoda }\end{array}$ & DIP & $\begin{array}{l}\text { Eudigraphis } \\
\text { taiwanensis }\end{array}$ & Transcriptome & $\begin{array}{c}\text { Fernández et al. } \\
2016 \\
\end{array}$ & SRR3458640 & Spe13 & $\begin{array}{l}\text { Eudigraphis } \\
\text { taiwanensis }\end{array}$ \\
\hline $\begin{array}{l}\text { Myriapoda, } \\
\text { Diplopoda }\end{array}$ & DIP & Cyliosoma sp. & Transcriptome & $\begin{array}{c}\text { Fernández et al. } \\
2016\end{array}$ & SRR3458641 & Spe14 & Cyliosoma sp. \\
\hline $\begin{array}{c}\text { Myriapoda, } \\
\text { Diplopoda }\end{array}$ & DIP & Brachycybe sp. & Transcriptome & $\begin{array}{c}\text { Brewer \& Bond } \\
2013 \\
\end{array}$ & SRR945430 & Spe15 & Brachycybe sp. \\
\hline $\begin{array}{l}\text { Myriapoda, } \\
\text { Diplopoda }\end{array}$ & DIP & Epanerchodus sp. & Transcriptome & This study & & Spe16 & Epanerchodus sp. \\
\hline $\begin{array}{l}\text { Myriapoda, } \\
\text { Diplopoda }\end{array}$ & DIP & Skleroprotopus sp. & Transcriptome & This study & SRR1145732 & Spe17 & Skleroprotopus sp. \\
\hline $\begin{array}{l}\text { Myriapoda, } \\
\text { Diplopoda }\end{array}$ & DIP & $\begin{array}{c}\text { Callipus } \\
\text { foetidissimus }\end{array}$ & Transcriptome & Szucsich et al., 2020 & SRR3485975 & Spe42 & $\begin{array}{c}\text { Callipus } \\
\text { foetidissimus }\end{array}$ \\
\hline $\begin{array}{l}\text { Myriapoda, } \\
\text { Diplopoda }\end{array}$ & DIP & $\begin{array}{c}\text { Craspedosoma sp. } \\
{[A D-2016]}\end{array}$ & Transcriptome & Szucsich et al., 2020 & SRR3485977 & Spe43 & $\begin{array}{c}\text { Craspedosoma sp. } \\
{[A D-2016]}\end{array}$ \\
\hline $\begin{array}{l}\text { Myriapoda, } \\
\text { Diplopoda }\end{array}$ & DIP & $\begin{array}{c}\text { Haploglomeris } \\
\text { multistriata }\end{array}$ & Transcriptome & Szucsich et al., 2020 & SRR3485985 & Spe44 & $\begin{array}{c}\text { Haploglomeris } \\
\text { multistriata }\end{array}$ \\
\hline Myriapoda, & DIP & Glomeridella minima & Transcriptome & Szucsich et al., 2020 & SRR3485983 & Spe45 & Glomeridella minima \\
\hline
\end{tabular}




\begin{tabular}{|c|c|c|c|c|c|c|c|}
\hline Diplopoda & & & & & & & \\
\hline $\begin{array}{l}\text { Myriapoda, } \\
\text { Diplopoda }\end{array}$ & DIP & $\begin{array}{c}\text { Ommatoiulus } \\
\text { sabulosus }\end{array}$ & Transcriptome & Szucsich et al., 2020 & SRR1653222 & Spe46 & $\begin{array}{c}\text { Ommatoiulus } \\
\text { sabulosus }\end{array}$ \\
\hline $\begin{array}{l}\text { Myriapoda, } \\
\text { Diplopoda }\end{array}$ & DIP & $\begin{array}{c}\text { Thalassisobates } \\
\text { littoralis }\end{array}$ & Transcriptome & Szucsich et al., 2020 & SRR1653242 & Spe47 & $\begin{array}{c}\text { Thalassisobates } \\
\text { littoralis }\end{array}$ \\
\hline $\begin{array}{l}\text { Myriapoda, } \\
\text { Diplopoda }\end{array}$ & DIP & $\begin{array}{l}\text { Polydesmus } \\
\text { complanatus }\end{array}$ & Transcriptome & Szucsich et al., 2020 & SRR3485993 & Spe48 & $\begin{array}{l}\text { Polydesmus } \\
\text { complanatus }\end{array}$ \\
\hline $\begin{array}{l}\text { Myriapoda, } \\
\text { Diplopoda }\end{array}$ & DIP & Polyxenus lagurus & Transcriptome & Szucsich et al., 2020 & SRR3485994 & Spe49 & Polyxenus lagurus \\
\hline $\begin{array}{l}\text { Myriapoda, } \\
\text { Diplopoda }\end{array}$ & DIP & $\begin{array}{l}\text { Polyzonium } \\
\text { germanicum }\end{array}$ & Transcriptome & Szucsich et al., 2020 & SRR3485995 & Spe50 & $\begin{array}{l}\text { Polyzonium } \\
\text { germanicum }\end{array}$ \\
\hline $\begin{array}{l}\text { Myriapoda, } \\
\text { Pauropoda }\end{array}$ & PAU & Pauropus huxleyi & Transcriptome & $\begin{array}{c}\text { Fernández et al. } \\
2017\end{array}$ & SRR6145369 & Spe10 & Pauropus huxleyi \\
\hline $\begin{array}{l}\text { Myriapoda, } \\
\text { Pauropoda }\end{array}$ & PAU & Acopauropus ornatus & Transcriptome & Szucsich et al., 2020 & SRR3485973 & Spe51 & Acopauropus ornatus \\
\hline $\begin{array}{l}\text { Myriapoda, } \\
\text { Symphyla }\end{array}$ & SYM & Scutigerella sp & Transcriptome & $\begin{array}{c}\text { Fernández et al. } \\
2014\end{array}$ & SRR3458649 & Spe07 & Scutigerella sp \\
\hline $\begin{array}{l}\text { Myriapoda, } \\
\text { Symphyla }\end{array}$ & SYM & Hanseniella sp. & Transcriptome & $\begin{array}{c}\text { Fernández et al. } \\
2016\end{array}$ & SRR6217953 & Spe08 & Hanseniella sp. \\
\hline $\begin{array}{l}\text { Myriapoda, } \\
\text { Symphyla }\end{array}$ & SYM & Symphylella sp. & Transcriptome & $\begin{array}{c}\text { Fernández et al. } \\
2017\end{array}$ & SRR6144316 & Spe09 & Symphylella sp. \\
\hline $\begin{array}{l}\text { Myriapoda, } \\
\text { Symphyla }\end{array}$ & SYM & Hanseniella nivea & Transcriptome & Szucsich et al., 2020 & SRR3485984 & Spe52 & Hanseniella nivea \\
\hline Chelicerata & CHE & Liphistius malayanus & Transcriptome & Sharma et al. 2014 & SRR1145736 & Spe18 & Liphistius malayanus \\
\hline Chelicerata & CHE & Centruroides vittatus & Transcriptome & Sharma et al. 2014 & SRR1146578 & Spe19 & Centruroides vittatus \\
\hline Chelicerata & CHE & Damon diadema & Transcriptome & Szucsich et al., 2020 & SRR3485979 & Spe25 & Damon diadema \\
\hline Chelicerata & $\mathrm{CHE}$ & $\begin{array}{c}\text { Archegozetes } \\
\text { longisetosus }\end{array}$ & Transcriptome & Szucsich et al., 2020 & SRR1653174 & Spe26 & $\begin{array}{c}\text { Archegozetes } \\
\text { longisetosus }\end{array}$ \\
\hline
\end{tabular}




\begin{tabular}{|c|c|c|c|c|c|c|c|}
\hline Chelicerata & $\mathrm{CHE}$ & Araneus diadematus & Transcriptome & Szucsich et al., 2020 & SRR3485974 & Spe27 & Araneus diadematus \\
\hline Chelicerata & $\mathrm{CHE}$ & Egaenus convexus & Transcriptome & Szucsich et al., 2020 & SRR3485980 & Spe28 & Egaenus convexus \\
\hline Chelicerata & $\mathrm{CHE}$ & Euscorpius sicanus & Transcriptome & Szucsich et al., 2020 & SRR1653192 & Spe29 & Euscorpius sicanus \\
\hline Chelicerata & $\mathrm{CHE}$ & Nymphon gracile & Transcriptome & Szucsich et al., 2020 & SRR1653221 & Spe30 & Nymphon gracile \\
\hline Onychophora & ONY & Peripatopsis capensis & Transcriptome & Szucsich et al., 2020 & SRR1145776 & Spe23 & $\begin{array}{c}\text { Peripatopsis } \\
\text { capensis }\end{array}$ \\
\hline Onychophora & ONY & $\begin{array}{c}\text { Peripatoides } \\
\text { novaezealandiae }\end{array}$ & Transcriptome & Szucsich et al., 2020 & SRR3485992 & Spe24 & $\begin{array}{c}\text { Peripatoides } \\
\text { novaezealandiae }\end{array}$ \\
\hline Crustacea & PAN & Daphnia pulex & Genome & & -- & Spe20 & Daphnia pulex \\
\hline Crustacea & PAN & Folsomia candida & Genome & & -- & Spe21 & Folsomia candida \\
\hline Crustacea & PAN & $\begin{array}{c}\text { Drosophila } \\
\text { melanogaster }\end{array}$ & Genome & & -- & Spe22 & $\begin{array}{c}\text { Drosophila } \\
\text { melanogaster }\end{array}$ \\
\hline Crustacea & PAN & Eubranchipus grubii & Transcriptome & Szucsich et al., 2020 & SRR1653190 & Spe53 & Eubranchipus grubii \\
\hline Crustacea & PAN & Triops cancriformis & Transcriptome & Szucsich et al., 2020 & SRR1653248 & Spe54 & Triops cancriformis \\
\hline Crustacea & PAN & Nebalia bipes & Transcriptome & Szucsich et al., 2020 & SRR1653215 & Spe55 & Nebalia bipes \\
\hline Crustacea & PAN & Anaspides tasmaniae & Transcriptome & Szucsich et al., 2020 & SRR1653173 & Spe56 & Anaspides tasmaniae \\
\hline Crustacea & PAN & $\begin{array}{c}\text { Hemidiaptomus } \\
\text { amblyodon }\end{array}$ & Transcriptome & Szucsich et al., 2020 & SRR1653196 & Spe57 & $\begin{array}{c}\text { Hemidiaptomus } \\
\text { amblyodon }\end{array}$ \\
\hline Crustacea & PAN & Tisbe furcata & Transcriptome & Szucsich et al., 2020 & SRR1653244 & Spe58 & Tisbe furcata \\
\hline Crustacea & PAN & Vargula hilgendorfii & Transcriptome & Szucsich et al., 2020 & SRR1811940 & Spe59 & Vargula hilgendorfii \\
\hline Crustacea & PAN & $\begin{array}{l}\text { Xibalbanus } \\
\text { tulumensis }\end{array}$ & Transcriptome & Szucsich et al., 2020 & SRR1653240 & Spe60 & $\begin{array}{l}\text { Xibalbanus } \\
\text { tulumensis }\end{array}$ \\
\hline
\end{tabular}

1 


\section{Table 2 (on next page)}

Results_of_topology_tests

Results of approximately unbiased (AU), weighted Kishino-Hasegawa $(\mathrm{KH})$, and weighted Shimodaira-Hasegawa (SH) tests comparing historically proposed hypotheses of the inner relationships of Myriapoda. A total of 100,000 RELL replicates were performed for each test, plus signs (+) denote the $95 \%$ confidence sets (not rejected), minus signs (-) denote significant exclusion (rejected). 


\begin{tabular}{ccccccc}
\hline \multirow{2}{*}{ Occ100 } & \multicolumn{2}{c}{ Pau-test } & \multicolumn{2}{c}{ Pkh-test } & \multicolumn{2}{c}{ Psh-test } \\
\cline { 2 - 7 } & ExcludeCHE & ExcludePAN & ExcludeCHE & ExcludePAN & ExcludeCHE & ExcludePAN \\
\hline Hypothesis Eda.1 & $0.6200+$ & $0.2110+$ & $0.5300+$ & $0.1320+$ & $1.0000+$ & $0.5310+$ \\
Hypothesis Eda.2 & $0.2950+$ & $0.9320+$ & $0.2330+$ & $0.8680+$ & $0.6130+$ & $1.0000+$ \\
Hypothesis Eda.3 & $0.0101-$ & $0.1630+$ & $0.0341-$ & $0.1010+$ & $0.1490+$ & $0.4840+$ \\
Hypothesis Dig.1 & $0.0088-$ & $0.1210+$ & $0.0925+$ & $0.0832+$ & $0.1630+$ & $0.1440+$ \\
Hypothesis Dig.2 & $0.0805+$ & $0.0372-$ & $0.1380+$ & $0.0194-$ & $0.3380+$ & $0.1360+$ \\
Hypothesis Dig.3 & $0.5410+$ & $0.0302-$ & $0.4700+$ & $0.0177-$ & $0.8100+$ & $0.0398-$ \\
\hline
\end{tabular}

\begin{tabular}{ccccccc}
\hline \multirow{2}{*}{ Occ90 } & \multicolumn{2}{c}{ Pau-test } & \multicolumn{2}{c}{ Pkh-test } & \multicolumn{2}{c}{ Psh-test } \\
\cline { 2 - 7 } & ExcludeCHE & ExcludePAN & ExcludeCHE & ExcludePAN & ExcludeCHE & ExcludePAN \\
\hline Hypothesis Eda.1 & $1.0000+$ & $0.7770+$ & $1.0000+$ & $0.7770+$ & $1.0000+$ & $1.0000+$ \\
Hypothesis Eda.2 & $3.62 \mathrm{E}-38-$ & $0.2230+$ & $0.0000-$ & $0.2230+$ & $1.00 \mathrm{E}-05-$ & $0.5570+$ \\
Hypothesis Eda.3 & $2.85 \mathrm{E}-50-$ & $4.15 \mathrm{E}-87-$ & $0.0000-$ & $0.0000-$ & $0.0000-$ & $0.0039-$ \\
Hypothesis Dig.1 & $9.72 \mathrm{E}-121-$ & $4.44 \mathrm{E}-110-$ & $0.0000-$ & $0.0000-$ & $0.0000-$ & $0.0000-$ \\
Hypothesis Dig.2 & $2.21 \mathrm{E}-91-$ & $5.15 \mathrm{E}-55-$ & $0.0000-$ & $0.0000-$ & $0.0000-$ & $0.0000-$ \\
Hypothesis Dig.3 & $1.09 \mathrm{E}-37-$ & $3.04 \mathrm{E}-11-$ & $0.0000-$ & $0.0000-$ & $1.00 \mathrm{E}-05-$ & $0.0000-$ \\
\hline
\end{tabular}

1 


\section{Table 3 (on next page)}

Distribution_of_LIT_genes_identification

Statistical results of LIT gene identification. Sum: the sum of transcripts from a specific class that was identified as LIT genes involved in a specific visual pathway. Max: the maximum quantity of transcripts from a species among a specific class that was identified as the LIT genes involved in a specific visual pathway. Mean: ratio of the sum and species quantity of a specific class. 


\begin{tabular}{|c|c|c|c|c|c|c|c|c|c|c|c|c|}
\hline & \multicolumn{3}{|c|}{ CHI } & \multicolumn{3}{|c|}{ DIP } & \multicolumn{3}{|c|}{ PAU } & \multicolumn{3}{|c|}{ SYM } \\
\hline & unique & sum & $\max$ & unique & sum & $\max$ & unique & sum & $\max$ & unique & sum & $\max$ \\
\hline rdn & 0 & 0 & 0 & 0 & 0 & 0 & 0 & 0 & 0 & 0 & 0 & 0 \\
\hline pre & 8 & 20 & 8 & 10 & 35 & 8 & 6 & 6 & 5 & 10 & 12 & 9 \\
\hline rtrans & 12 & 179 & 12 & 12 & 170 & 12 & 12 & 24 & 12 & 12 & 44 & 12 \\
\hline ctrans & 11 & 139 & 11 & 12 & 153 & 11 & 10 & 19 & 10 & 10 & 31 & 10 \\
\hline retv & 7 & 102 & 7 & 7 & 99 & 7 & 7 & 13 & 7 & 7 & 24 & 7 \\
\hline reti & 4 & 8 & 4 & 5 & 18 & 4 & 0 & 0 & 0 & 5 & 10 & 5 \\
\hline mel & 8 & 116 & 8 & 8 & 100 & 8 & 7 & 13 & 7 & 8 & 23 & 8 \\
\hline pter & 8 & 81 & 8 & 8 & 56 & 8 & 6 & 12 & 6 & 8 & 18 & 8 \\
\hline ommo & 7 & 48 & 7 & 7 & 53 & 7 & 1 & 2 & 1 & 7 & 13 & 7 \\
\hline heme & 7 & 27 & 7 & 8 & 22 & 7 & 7 & 14 & 7 & 7 & 8 & 7 \\
\hline crys & 5 & 34 & 4 & 5 & 22 & 4 & 1 & 2 & 1 & 1 & 4 & 1 \\
\hline clock & 12 & 114 & 12 & 12 & 87 & 10 & 6 & 6 & 6 & 11 & 20 & 10 \\
\hline opsin & 0 & 0 & 0 & 0 & 0 & 0 & 0 & 0 & 0 & 0 & 0 & 0 \\
\hline
\end{tabular}

1

\begin{tabular}{|c|c|c|c|c|c|c|c|c|c|c|c|c|c|c|c|c|}
\hline & \multicolumn{4}{|c|}{ CHI } & \multicolumn{4}{|c|}{ DIP } & \multicolumn{4}{c|}{ PAU } & \multicolumn{4}{c|}{ SYM } \\
\hline & unique & sum & max & mean & unique & sum & $\max$ & mean & unique & sum & max & mean & unique & sum & max & mean \\
\hline rdn & 0 & 0 & 0 & 0.00 & 0 & 0 & 0 & 0.00 & 0 & 0 & 0 & 0.00 & 0 & 0 & 0 & 0.00 \\
\hline prc & 8 & 20 & 8 & 1.18 & 10 & 35 & 8 & 2.19 & 6 & 6 & 5 & 3.00 & 10 & 12 & 9 & 3.00 \\
\hline rtrans & 12 & 179 & 12 & 10.53 & 12 & 170 & 12 & 10.63 & 12 & 24 & 12 & 12.00 & 12 & 44 & 12 & 11.00 \\
\hline ctrans & 11 & 139 & 11 & 8.18 & 12 & 153 & 11 & 9.56 & 10 & 19 & 10 & 9.50 & 10 & 31 & 10 & 7.75 \\
\hline retv & 7 & 102 & 7 & 6.00 & 7 & 99 & 7 & 6.19 & 7 & 13 & 7 & 6.50 & 7 & 24 & 7 & 6.00 \\
\hline reti & 4 & 8 & 4 & 0.47 & 5 & 18 & 4 & 1.13 & 0 & 0 & 0 & 0.00 & 5 & 10 & 5 & 2.50 \\
\hline mel & 8 & 116 & 8 & 6.82 & 8 & 100 & 8 & 6.25 & 7 & 13 & 7 & 6.50 & 8 & 23 & 8 & 5.75 \\
\hline pter & 8 & 81 & 8 & 4.76 & 8 & 56 & 8 & 3.50 & 6 & 12 & 6 & 6.00 & 8 & 18 & 8 & 4.50 \\
\hline ommo & 7 & 48 & 7 & 2.82 & 7 & 53 & 7 & 3.31 & 1 & 2 & 1 & 1.00 & 7 & 13 & 7 & 3.25 \\
\hline heme & 7 & 27 & 7 & 1.59 & 8 & 22 & 7 & 1.38 & 7 & 14 & 7 & 7.00 & 7 & 8 & 7 & 2.00 \\
\hline
\end{tabular}




\begin{tabular}{|c|c|c|c|c|c|c|c|c|c|c|c|c|c|c|c|c|}
\hline crys & 5 & 34 & 4 & 2.00 & 5 & 22 & 4 & 1.38 & 1 & 2 & 1 & 1.00 & 1 & 4 & 1 & 1.00 \\
\hline clock & 12 & 114 & 12 & 6.71 & 12 & 87 & 10 & 5.44 & 6 & 6 & 6 & 3.00 & 11 & 20 & 10 & 5.00 \\
\hline opsin & 0 & 0 & 0 & 0.00 & 0 & 0 & 0 & 0.00 & 0 & 0 & 0 & 0.00 & 0 & 0 & 0 & 0.00 \\
\hline
\end{tabular}

